\title{
THE ADOPTION OF AN M-LEARNING POLICY IN HIGHER EDUCATION: THE PROFESSIONALS' PERSPECTIVE IN DEVELOPING COUNTRIES
}

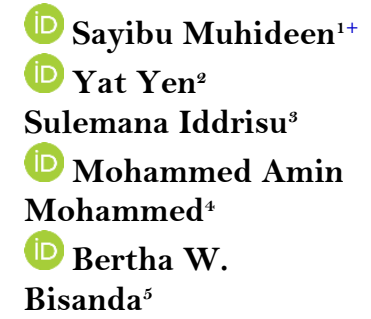

\author{
${ }^{1,2,5}$ School of Public Affairs, University of Science and Technology of China, \\ Hefei 230026, Anhui, China. \\ 'Email:deen2@mail.ustc.edu.cn \\ 'Email:yy2014@mail.ustc.edu.cn \\ ${ }^{3,4}$ Tamale College of Education, Tamale 020816645, Ghana. ${ }^{s t}$ University of \\ Professional Studies, P.O. Box LG 149, Legon, Accra, Ghana. \\ sEmail:sulesakabu@yahoo.com \\ ${ }^{4}$ Email:aminmohammed902@gmail.com
}

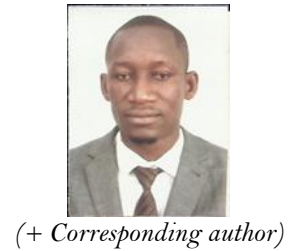

\section{Article History}

Received: 4 December 2018 Revised: 8 January 2019 Accepted: 14 February 2019 Published: 12 April 2019

\section{Keywords}

M-learning

Policy innovation Higher education Mobile learning

\begin{abstract}
In this digital age, e-learning has developed rapidly from web-based searches to mobile learning. This study aims to identify an M-learning policy for high schools in developing countries. An expanded theory of planned behavior framework, comprising the core constructs and the additional variables of enabling environment and experience, is employed to predict the significance of adopting M-learning among learners. The data is collected via social media and emails, and analyzed using Smart PLS-SEM 3.0. Of the 205 students completing the questionnaire, $38.5 \%$ were male and $61.5 \%$ female. The results indicate a satisfactory $\mathrm{R}^{2}$ of adoption intention (0.157) for all the variables and moderator, and the school setting is significant for the adoption of an M-learning policy; thus, it is suggested that government policy is a crucial factor to its acceptance in any learning setting. The ubiquity of mobile devices is unavoidable, and an innovative approach could lead to the effective application of this technology in education. A government policy will encourage and strengthen such effectiveness among scholars in developing countries.
\end{abstract}

Contribution/Originality: This study contributes to the existing literature and discourse on M-learning with the intention to use the innovation in schools, due to learners' experience of with the technology in high schools. Mlearning complements e-learning and ICT in driving development in many socioeconomic endeavors for developing economies, especially the subregions on the African continent.

\section{INTRODUCTION}

In the age of technological innovation, most activities and resources are tailored toward information and communication technologies for development (ICT4D) (Kabanda and Brown, 2017). The novelty of mobile learning technology in education shapes today's students in an informal setting, but is challenging for different sociocultural environments (Peeters et al., 2014). This technology comprises any learning innovation based on a flexible and portable handheld device acting as an interface to information and knowledge (Li, 2016) thus, M-learning, or learning while on the move, is accessible from wireless-enabled personal digital assistants (PDAs), smartphones, iPads, tablets (Mehdipour and Zerehkafi, 2013). Recent guidelines from UNESCO highlight the current behavior of learners in higher education, the significant role of an M-learning policy, and that almost every student owns a mobile device in most developing countries (West and Vosloo, 2013). Studies have identified a larger scale of informal M-learning, which is a concern for policymakers and stakeholders enhancing and transforming educational 
technology in high schools and colleges among low-income economies (Karimi, 2016; Osakwe et al., 2017). Concerns raised by scholars are related to the reliability of the technology and its impact on education; thus, many educationalists and researchers should chart the technological innovation principles of UNESCO.

With the current cloud environment, the digital age facilitates learners' and professionals' use of information communication technology via a mobile device (Quaye, 2015). Study undertaken through hypertext and social network learning environments, though, is a whole new pedagogy for some teachers who adopt the expertise approach (Serrano-Laguna et al., 2014). Studies on the process, strategic implementation, and evaluation of mobile learning utilization is based on professionals and authorities in schools (Sung et al., 2016; Khan et al., 2018). Findings reveal that students' behavior in using smartphones empowers student-centered learning, which in turn enhances cognitive ability to undertake inquiry-based and discovery learning (Pegrum et al., 2013; Kabanda and Brown, 2017). The sociocultural misconceptions and perceptions about M-learning technology should be resolved through enlightenment. However, the ability of teachers and learners to integrate teaching methods with the technological innovation of M-learning is only achievable through regulatory legislation, which itself requires the appropriate environment and cultural understanding of the concept (Osakwe et al., 2017). The adoption of an Mlearning policy requires a stepwise approach to resolve specific educational bottlenecks: infrastructure, e-reading, ICT, e-learning, and the logistic need of schools, at a cognitive level (Dedrick et al., 2013). The same principles apply to an ICT implementation policy, although it is the learners themselves who invest in M-learning. Previous studies have examined the skills and experiences of the learners using mobile devices and suggested ways to facilitate technological innovations in schools (West and Vosloo, 2013).

Moreover, mobile devices are often used outside the classroom for sharing knowledge and for informative learning. Despite their role as a learning catalyst in higher education, in most developing countries, such as Ghana, Nigeria, Sierra Leone, Cameroon, and Rwanda, mobile devices are banned in schools. Nevertheless, the concern of professionals is not simply from a fear of being sidelined; empirical evidence shows there is a responsibility to ensure the safe use of mobile devices, which is essential for an efficient and effective implementation framework (West and Vosloo, 2013). UNESCO research has shown such a ban on mobile devices causes more harm than good: due to the ubiquity of mobile devices, the formal education system must adopt these innovations to enhance efficient student-centered education in the achievement of study goals (Ireri and Omwenga, 2016). Indeed, studies have found that the use of M-learning in schools better helps students discover and understand the meaning of words than in the classroom (Looi et al., 2014). On the other hand, the professionals' perspective of the technology is respected, and teaching methods should be regulated (Kimiloglu et al., 2017). Hence, the aim of this study is to encourage the regulated use of M-learning in schools, to stimulate student-centered learning in an informal setting (Sung et al., 2016). Research findings from personalized accounts of stakeholders and professionals reveal most individual users of M-learning are given the freedom to learn without instructors or other assistance (Yagci, 2015). By enabling student-learning activities in schools, M-learning supports the setting of assignments and exercises (Beutner and Rüscher, 2017). The adoption of the technology is not retrogression but progression; therefore, rules and regulations for M-learning implementation are essential for the prosperous socioeconomic and educational development of low-income countries (Sobaih et al., 2016).

Furthermore, Brahimi and Sarirete (2015) argue that technology consists of networks, instructors, and learners, both inside and outside schools, that contribute to the success of learning and knowledge acquisition, and positive attitudes toward M-learning (Brahimi and Sarirete, 2015). M-learning as a complement to distance education has aided the affordability of learning (Park, 2011) many research studies accept M-learning as a subset of e-learning, which has long been in use in developed, although not necessarily developing, countries (Al-alak and Alnawas, 2011). A study of the potential of M-learning and its ability to streamline technological assessment, providing immediate feedback on all activities to learners and teachers, demonstrates a novel application of technology that efficiently automates the distribution, collection, and evaluation of assignments and associated 
documentation (Wongwatkit et al., 2017). This research study will empirically analyze: (1) the policy of adopting Mlearning in higher education, including the professionals' perspective in developing countries; (2) how a technological policy will effectively support academic performance in high schools of developing countries.

\subsection{Background Study to M-Learning Policy}

Recently, mobile learning (M-learning) has become a crucial study tool among educationalists and professionals in learning institutions (Sayibu et al., 2018). The assimilation of modern technological innovations among learners has introduced a different aspect, which has affected a breakthrough in policy: ICT is increasingly becoming a significant tool in teaching and learning, one example of which is the use of WeChat, a social media tool, by Chinese students to share lecture materials and relevant resources (Yagci, 2015). The rapid growth of ICT originated with the use of mainframe followed by desktop computers in the 1970s, leading to the development of tablets and then smartphones (Castillo and Ayala, 2012).

"We cannot always build the future for our youth, but we can build our youth for the future."

Franklin D, Roosevelt, September 20, 1940, Address at University of Pennsylvania

With changing marketing/educational trends, today's learners are being educated for jobs with different strategic technological innovations; thus, the above quotation remains important in advocating the need for public policy on M-learning and other technologies in education. The rapid growth in creative technological ideas and shaping young people for the future requires social consciousness (Castillo and Ayala, 2012). Academic institutions are far more resourceful with technology than previously, particularly in terms of mobile connectivity, which is key to sustainable improvement in educational reorganization and restructuring (Abu-Al-Aish, 2014). The features and smooth implementation of mobile technology have provided a significant breakthrough for the educational system: learners now have new experiences in schools, quite different from the past (Bird and Stubbs, 2015).

In 1954, Skinner (1971) forecasted the use of technology in education. His teaching machine, a very early and unwieldy computer, was similar to today's mobile technology in revolutionizing classroom learning for students: they were given the opportunity to learn independently using targeted, self-paced lessons. Skinner's predictions anticipate the modern-day computers, netbooks, and other technologies, but why did it not succeed in 1954? The innovation of mobile technology is quite different and peculiar to today's educational setting. The concept of computers in schools was a dramatic change and made little progress in the educational context; Skinner's teaching machine was a novelty that made only a minimal contribution to the traditional classroom setting. Since then though, computers have developed and transformed, becoming smaller and more effective and efficient, which has enabled their rapid adoption in the classroom. Computers were first used in education for data storage in the 1960s. Eventually, in the 1980s, the Apple II mainframe computer became available worldwide. Then, the teaching of ICT, during K12 education predominantly, expanded in the 1990s. The need to connect all classrooms to the internet was realized with the emergence of desktop computers, laptops, and netbooks, while Apple released its iPad in 2010 (Levy, 2015). The introduction of the tablet computer stimulated the further innovations of touchscreens, increased portability, Wi-Fi, and intuitive user interfaces (Drigas and Pappas, 2015).

While the iPad signaled a significant change in digital learning, other Android-based tablets developed, resulting in Acer and Asus entering the market in 2013 as the top netbook producers. Although difficult to imagine, the widespread use of tablets and all their functions, despite some misapplication, has grown without any calls for public policy or regulations. With technological changes over a period of 60 years ending in a handheld device that fits in the user's pocket, M-learning technology has enhanced teaching and learning for most teachers and learners (Burden and Kearney, 2017). In fact it is currently the most promising technology as a learning tool; therefore, a policy is crucial for embedding its use in education (Borrás and Edquist, 2013). Mobile technology will enable personalized learning on the move, a change that will revolutionize the education system. In the significant words of Gates (2009): 
"The world of education is the sector of the economy so far the least changed by technology. Ten years from now that won't be the case."

Now we are in the $21^{\text {st }}$ century, smart implementation of mobile technology and a progressive educational policy can lead the way to M-learning (Crompton, 2013). The above quote can therefore be seen as calling on legislatures "to think outside the box," because the potential of mobile devices as learning tools will not cease.

\subsection{Theory of Planned Behavior (TPB)}

The theory of planned behavior (TPB) originally evolved from the theory of reasoned action (TRA) (SongerNocks, 1976); (Fishbein and Cappella, 2006) which had been used to examine behavior in relation to the adoption of information systems (Ajzen, 1991). This is only one of many psychological models for predicting behavior that is employed in this study. Conceptually, TPB comprises several independent antecedents: behavioral intention (BI), attitude toward behavior (ATB), subjective norms (SN), and perceived behavioral control (PBC). ATB is the assessment of intended action or events, which is positive or negative when executed (Ajzen, 1991): The attitude of learners and teachers in schools suggests a strong desire for the adoption of M-learning. SN refers to users' perception of social laws, norms, and attitudes that could determine whether an action, such as regulatory measures for teachers, is accepted, by school authorities for instance (Ajzen, 1991). PBC is the users' belief of how easy or difficult an action will be to perform: if the school authorities facilitate the implementation and use of M-learning, then its adoption is more probable (Ajzen, 1991). Therefore, an M-learning policy must take into account users' PBC to benefit from its positive influence on attitudes, culture, authority, beliefs, and SNs. The adoption of technology is also easily affected by expectations, perceived usefulness (PU), and perceived ease of use (PEOU), but these extended factors are not included in this study (Venkatesh et al., 2003).

\subsubsection{Expanded TPB Framework}

The existing model of TPB (ATB, SN, PBC) is expanded for the adoption of M-learning in higher education by means of enabling environment (EE) and experience as moderator (Ajzen, 1991; Wada, 2018). Enabling Environment is the physical or social setting that enables knowledge acquisition in a tranquil atmosphere (Noar and Zimmerman, 2005). In this context, the environment, people, and behavior are intertwined, of which the last, although in the background, Noar and Zimmerman (2005) can determine learners' adoption of M-learning in school. Experience as moderator refers to learners' exposure to technology, the skills and knowledge acquired over time, and the sense of purpose in using mobile devices (Crogman and Trebeau Crogman, 2018) thus, the learners' use of M-learning in school can create a playful learning environment in which learners are motivated to engage and learn unconsciously (Kangas et al., 2017). Such covert use of mobile devices by learners over a long period greatly influences their adoption of M-learning, enhancing its efficiency. Experience as a moderator expresses the author's observation as a professional teacher of learners' attitudes toward using mobile devices and demonstrates an undoubtedly positive effect (Yen et al., 2017). 


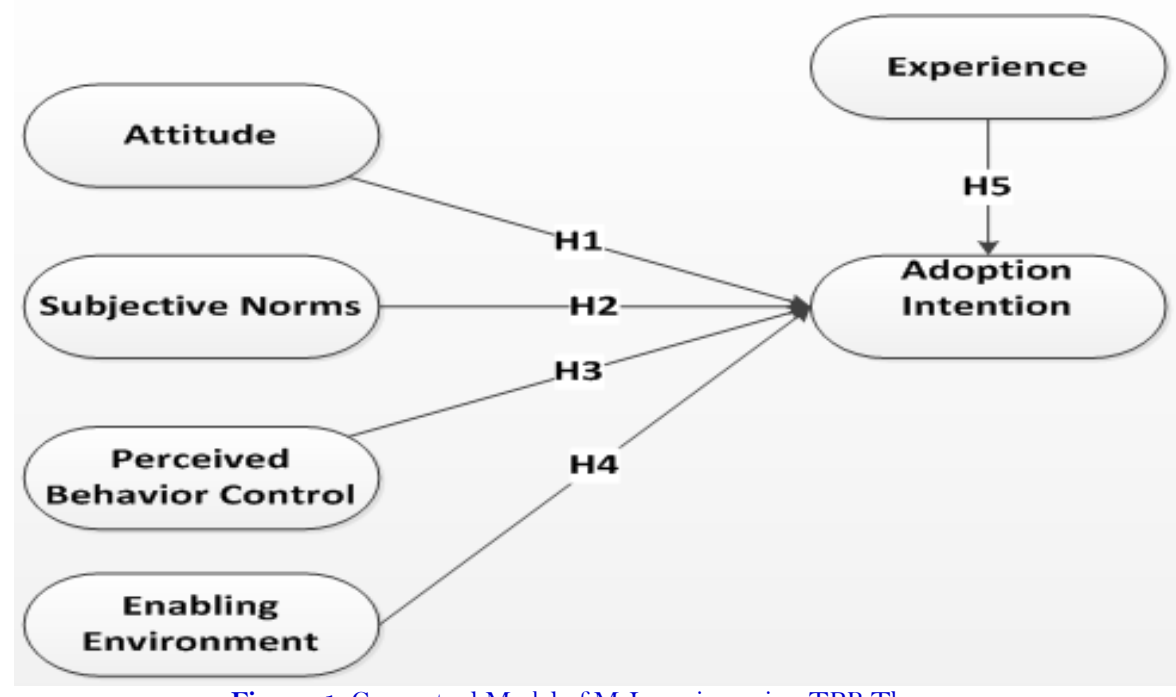

Figure-1. Conceptual Model of M-Learning using TPB Theory.

\subsubsection{Hypothesis}

H1: Attitude toward Behavior (ATB) positively influences the adoption intention (ADIN) for an M-learning policy in education.

H2: Subjective Norms (SN) are strongly related to the adoption intention (ADIN) for an M-learning policy.

H3 Perceived Behavioral Control (PBC) is strongly related to the adoption intention (ADIN) for an M-learning policy in higher education.

H4: Enabling Environment (EE) may be positively or negatively associated with the adoption intention policy for an M-learning in education.

H5: Experience (E2) moderates adoption intention (ADIN) to enhance the adoption of a policy.

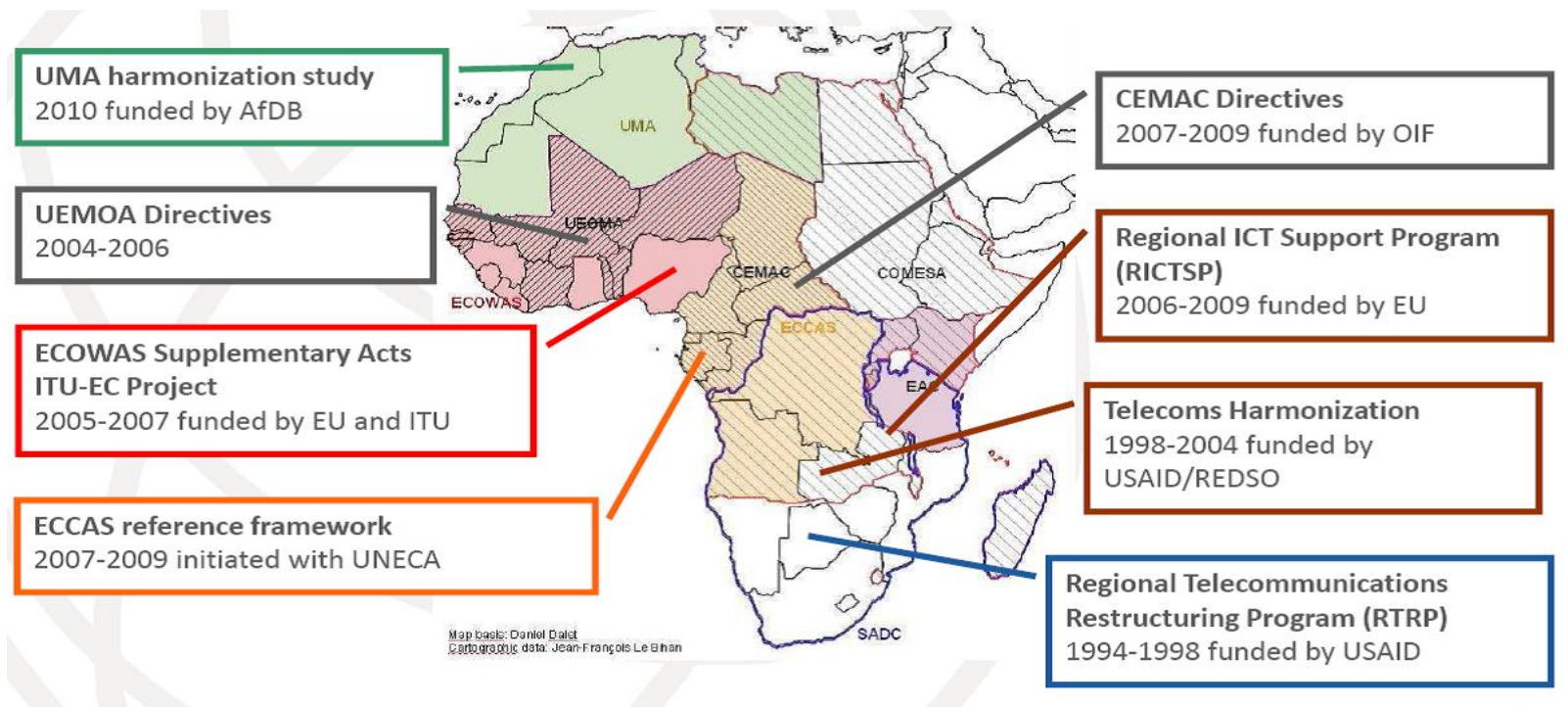

Source: African Page for Development.

Figure-2. Subregions on African Continent in Developing ICT.

\section{METHODS AND MATERIALS}

\subsection{Study Aims}

The author employed TPB in a triangulated approach, modified to investigate M-learning adoption through data and theory. A web-based questionnaire was created with Google (Levy, 2015) with each construct measured quantitatively by a 5-point Likert scale—ranging from (1) strongly disagree (SD), (2) disagree (D), (3) undecided (UD), (4) agree (A), to (5) strongly agree (SA) (Likert, 1932); Osakwe et al. (2017)—while qualitative means were 
used to collect demographic variables (Beglar and Nemoto, 2014). A stratified sampling technique was employed to select target participants: primary educationalists, and teachers and students in high schools, colleges, and universities (Venkatesh et al., 2003). Due to the interest in mobile learning, the research was undertaken via social media: a link to the questionnaire was randomly sent to students and teachers via WhatsApp and WeChat between January 2 and 29, 2018, with most teachers using it as a class assignment. A total of 255 participants were approached, of whom 205 responded (an $84.5 \%$ response rate). Seven high school teachers with expertise in ICT emailed the author personally to indicate their previous experience of using M-learning in some lessons, even without any policy. In fact, the majority of respondents were from high schools across developing countries, which were within this study's target population. Of the 205 respondents, 126 were female and 79 male, $79 \%$ and $38.5 \%$, respectively; Table 1 details the other demographic variables of age, educational level, region, and how long and how often (weekly, monthly, annually) they had used mobile phones.

The questionnaires were carefully and critically constructed in line with adoption of an M-learning policy. The model depicted in Figure 1 indicates the dimensions that streamline the various developmental needs for the key ICT component; the expanded TPB framework was the most appropriate for the questionnaire survey, including not only ATT, SN, PBC, and ADIN but also EE and E2.

\subsection{Model Measurements}

To assess the goodness of fit for the structural model, partial least squares structural equation modeling (PLSSEM) (Hair et al., 2013) was applied to the endogenous construct of adoption intention. To assess the validity and reliability, composite reliability (CR), convergent validity, and discriminant validity (Hair et al., 2013) were calculated. Where the CR lies between $O$ and 1 and logical validity between 0.7 and 0.9 , validity and reliability can be assumed satisfactory (Rönkkö and Ylitalo, 2011). Construct validity and reliability, plus average variance extracted (AVE) were also calculated: a loading higher than 0.70 on its respective construct indicates reliability (Hair et al., 2012a) the value of AVE should be $\geq 0.5$ (Fornell and Larcker, 2016), meaning a latent variable should be able to capture at least 50\% of each indicator's variance (Yen et al., 2017). Cronbach's $\alpha$ was used to measure the internal consistency reliability, which should be $\leq 0.70$ for each latent variable (Hair et al., 2013). Finally, the discriminant validity, according to Fornell-Lacker's criterion, will confirm whether the latent variables are distinctly different from one another (Hair et al., 2012a).

\subsection{Structural Models}

To measure the structural model, the values of R-squared $\left(\mathrm{R}^{2}\right)$, effect size (Cohen's $\left.\mathrm{f}^{2}\right)$, path coefficients ( $\mathrm{t}$ value), $\mathrm{Q}^{2}$ predictive relevance based on blindfolding, and collinearity were determined (Hair et al., 2013). According to Bodoff and Ho (2016) $\mathrm{R}^{2}$ values of 0.19-0.33, 0.33-0.67, and $\geq 0.67$ indicate low, moderate, and strong explanatory power; Hair et al. (2013) explained Crohn's $\mathrm{f}^{2}$ values of $0.02,0.15$, and 0.35 as weak, moderate, and strong effects; Aimran et al. (2017) emphasized that $Q^{2}>0$ indicates that the path model's predictive accuracy is acceptable. In calculating $Q^{2}$, the author adopted the cross-validated redundancy approach. Collinearity was assessed using the variance inflation factor (VIF), which is important because path coefficient estimates may be biased if collinearity is present (Henseler et al., 2015) a VIF value of $\geq 5$ implies a potential collinearity issue (Hair $e t$ al., 2012a).

\subsection{Data Analysis}

Descriptive statistical analyses of the demographic information related to the adoption intention for an Mlearning policy in developing countries were undertaken using IBM SPSS v.23.0 (IBM, Armonk, NY, USA). The reliability and validity of the variables in the models were measured and tested, following reliability analysis principles to validate Cronbach's $\alpha$. On the whole, a coefficient value of $\geq 0.70$ (Mcneish, 2017) is acceptable for 
Cronbach's $\alpha$ (IBM, 2015) in some analyses related to TPB (Bonett and Wright, 2015); (Xie et al., 2017). Table 1 shows the mean, mode, median, and standard deviation (SD) employed in a comparative study of gender, educational level, age, region, and the period of time that the sample population $(\mathrm{N}=205)$ had used advanced mobile phones (smartphones), to assess adoption intention. A mixed methodology of qualitative and quantitative data for triangulated studies was adopted for robust validity and reliability.

\section{RESULTS}

\subsection{Respondents' Characteristics}

As mentioned in the previous section, 205 responses-including 7 emails form those with educational ICT expertise in developing countries-were received from a total of 255 questionnaires, representing an $84.5 \%$ response rate $(61.5 \%$ female vs. $38.5 \%$ male). The high response rate can be explained by the online status of the target population and the interest among teachers, who assigned the task during ICT lessons via WhatsApp and WeChat, social media in common use among students.

Table-1. Demographic variable analysis.

\begin{tabular}{|c|c|c|c|c|c|c|c|c|}
\hline \multirow[t]{2}{*}{ Variables } & & & & & Mean & Median & Mode & SD \\
\hline & & $\mathbf{N}$ & $\%$ & TOTAL & & & & \\
\hline \multirow[t]{2}{*}{ Gender } & $\mathrm{F}$ & 126 & 61.5 & 205 & 1.39 & 1.00 & 1 & 0.488 \\
\hline & $\mathrm{M}$ & 79 & 38.5 & & & & & \\
\hline \multirow{4}{*}{$\begin{array}{l}\text { Education } \\
\text { SHS/NON }\end{array}$} & SHS 1 & 63 & 30.7 & 205 & 1.97 & 2.00 & 2 & 0.828 \\
\hline & $\mathrm{SHS} 2$ & 95 & 46.3 & & & & & \\
\hline & SHS 3 & 37 & 18.0 & & & & & \\
\hline & $\mathrm{NON}$ & 10 & 4.9 & & & & & \\
\hline \multirow[t]{3}{*}{ Age } & $18-25 y r s$ & 172 & 83.9 & 205 & 1.22 & 1.00 & 1 & 0.539 \\
\hline & $26-34 y r s$ & 21 & 10.2 & & & & & \\
\hline & $35-45$ yrs & 12 & 5.9 & & & & & \\
\hline \multirow[t]{10}{*}{ Region } & WA & 19 & 9.3 & 205 & 5.91 & 6.00 & 8 & 2.723 \\
\hline & ASM & 8 & 3.9 & & & & & \\
\hline & $\mathrm{PAH}$ & 10 & 4.9 & & & & & \\
\hline & WR & 26 & 12.7 & & & & & \\
\hline & $\mathrm{ER}$ & 15 & 7.3 & & & & & \\
\hline & IND & 25 & 12.2 & & & & & \\
\hline & $\mathrm{CRA}$ & 24 & 11.7 & & & & & \\
\hline & NRA & 49 & 23.9 & & & & & \\
\hline & UA & 18 & 8.8 & & & & & \\
\hline & $\mathrm{BAG}$ & 11 & 5.4 & & & & & \\
\hline \multirow[t]{2}{*}{ Period of Use } & $1-2 y r s$ & 2 & 1.0 & 205 & 3.99 & 4.00 & 4 & 0.099 \\
\hline & $>2$ yrs & 203 & 99.0 & & & & & \\
\hline \multirow[t]{2}{*}{ Frequency of Use } & Yes & 205 & 100 & 205 & 1.00 & 1.00 & 1 & 0.000 \\
\hline & $\mathrm{No}$ & - & - & & & & & \\
\hline
\end{tabular}

Note: SHS, senior high school; WA, West Africa; ASM, Asia China Main; PAH, Pakistan Region; WR, Western Africa; ER, Eastern Africa; IND, India Region; CRA, Central Africa; NRA, Northern Africa; UA, Western Region Africa; BAG, Bangladesh.

Teachers took the time to explain the instructions for and purpose of the questionnaire. A Cronbach's a value of 0.740 was generally calculated for all variables: the majority of respondents were 18-25 years' old $(\mathrm{N}=172$, $83.9 \%$ ), attained the highest educational level (SHS 1-3; $\mathrm{N}=195,95.1 \%$ ), had used mobile phones for two or more years $(\mathrm{N}=203,99.0 \%)$, and frequently used advanced smartphones $(\mathrm{N}=205,100 \%)$. Thus, this study conforms with the survey by Africa Internet Tracking Progress that found 72\% of young people in developing countries were mobile users (Ghana Statistical Service \& Ghana Demographic Health Survey, 2008). 


\subsection{Model Measurements}

In the path analysis, the lowest $\mathrm{CR}$ value is 0.53 for $\mathrm{SN}$, which is statistically satisfactory. Table 2 indicates the loadings range from 0.828, 0.813, 0.778, 0.685, 0.547, down to 0.526 for ADIN, ATB, E2, EE, PBC, and SN, respectively; only EE indicates a very low correlation. Furthermore, it can be seen from Table 2 that the weakest AVE in the study is again for EE at 0.489, which is slightly below the threshold value of 0.5 suggested by Claes and David (2012). Similarly, Cronbach's $\alpha$, which measures internal consistency reliability, exceeds 0.70 for all the latent variables (Hair et al., 2013) whereas the AVE ranges from 0.489 to 1.040, which is a clear indication of the quality of this model: statistically, its validity and reliability is satisfactory (Fornell and Larcker, 2016).

\subsection{Structural Model Quality}

In Table 2, experience as a moderator $(\mathrm{E} 2)$ has moderate power $\left(\mathrm{R}^{2}=0.326\right)$ on adoption intention $\left(\mathrm{ADIN} ; \mathrm{R}^{2}\right.$ $=0.157$ ), while other latent variables have weak: $\mathrm{R}^{2}=0.023, \mathrm{R}^{2}=-0.189, \mathrm{R}^{2}=1.081, \mathrm{R}^{2}=1.104$ for ATB, EE, $\mathrm{PBC}$, and SN, respectively. Also shown in Table 2 are the resulting values of cross-validated redundancy, where all $\mathrm{Q}^{2}$ were between 0.03 and $0.30: \mathrm{ATB}=0.219, \mathrm{ADIN}=0.248, \mathrm{E} 2=0.191, \mathrm{PBC}=0.082$, and $\mathrm{SN}=1.271$, representing the accuracy of these latent variables in predicting adoption intention.

Table-2. Reliability and validity of latent variables and internal loading.

\begin{tabular}{|c|c|c|c|c|c|c|c|c|c|c|c|c|c|}
\hline \multirow[t]{2}{*}{$\mathbf{L V}$} & \multicolumn{6}{|c|}{ Fornell-Larcker Criterion } & \multirow[b]{2}{*}{ IL } & \multirow[b]{2}{*}{$\boldsymbol{\alpha}$} & \multirow[b]{2}{*}{ CR } & \multirow[b]{2}{*}{ AVE } & \multirow[b]{2}{*}{ VIF } & \multirow[b]{2}{*}{$\mathbf{R}^{2}$} & \multirow[b]{2}{*}{$Q^{2}$} \\
\hline & ADIN & ATB & $\mathrm{E2}$ & EE & PBC & $\mathbf{S N}$ & & & & & & & \\
\hline ADIN & 0.747 & & & & & & $\begin{array}{l}0.747 \\
0.776 \\
0.740\end{array}$ & 0.742 & 0.828 & 0.543 & & 0.157 & 0.248 \\
\hline ATB & 0.140 & 0.702 & & & & & $\begin{array}{l}0.778 \\
0.828 \\
0.817 \\
0.717\end{array}$ & 0.733 & 0.813 & 0.535 & 1.084 & 0.023 & 0.219 \\
\hline E2 & 0.283 & 0.042 & 0.730 & & & & $\begin{array}{l}0.717 \\
0.749 \\
0.726 \\
0.864 \\
0.775 \\
\end{array}$ & 0.751 & 0.778 & 0.536 & 1.110 & 0.326 & 0.191 \\
\hline $\mathbf{E E}$ & -0.142 & -0.232 & 0.132 & 0.701 & & & $\begin{array}{l}0.751 \\
0.762 \\
0.718 \\
\end{array}$ & 0.771 & 0.685 & 0.489 & 1.082 & -0.189 & -0.301 \\
\hline PBC & 0.189 & 0.075 & 0.151 & 0.015 & 0.717 & & $\begin{array}{l}0.800 \\
0.874 \\
0.774 \\
\end{array}$ & 0.876 & 0.547 & 0.589 & 0.051 & 1.081 & 0.082 \\
\hline SN & O.149 & -0.048 & 0.275 & 0.230 & 0.241 & 0.76 & $\begin{array}{l}0.726 \\
0.749 \\
0.784 \\
0.702 \\
0.771\end{array}$ & 0.804 & 0.526 & 1.040 & 1.104 & 1.014 & 1.271 \\
\hline
\end{tabular}
variance extracted; VIF, variance inflation factor.

Finally, none of the VIF values from Table 2 were $\geq 5$, which represents no collinearity and thus no bias in the path coefficients. This study's $\mathrm{R}^{2}$ indicates moderate power for adoption intention in the developing subregions of the African continent, as well as other developing African nations excluded from the survey. Figure 2 is a map of Africa showing the various structural dimensions for regional development related to ICT in the educational policy framework (2006-2009). Specifically, the external funding indicated in Figure 2 for Telecoms Harmonization (1998-2004) to central Africa was part of the restructuring of the telecommunications industry in Africa; the development of an M-learning policy was part of this harmonization, to reform education through ICT, e-learning, and M-learning across the subcontinent by the government. 
Analyzing the hypotheses, all five demonstrated positive predictive levels; as can be seen in Table 3, the major constructs of (TPB) - attitude toward behavior (ATB), subjective norms (SN), perceived behavioral control (PBC), enabling environment (EE), and experience (E2) — are positively significant in relation to adoption intention (ADIN) for M-learning in higher education. H4: for EE's association with ADIN is significant $(\beta=0.173, \mathrm{M}=-$ $\left.0.085, \mathrm{t}=1.423, \mathrm{SD}=0.013, \mathrm{p}=0.000^{*} * \mathrm{f}^{2}=0.035\right)$ with $\mathrm{R}^{2}=-0.189$. This predictive significance is satisfactory, as with the other hypotheses that are all positively associated with adoption intention. The path coefficient of $\mathrm{H} 5$ for E2 moderating ADIN is significant $(\beta=0.269, \mathrm{M}=0.315, \mathrm{t}=3.065, \mathrm{SD}=0.106, \mathrm{p}=0.002 * *)$ and with $\mathrm{R}^{2}=0.326$, supported the hypothesis. All the other core constructs of TPB are also significantly related to adoption intention: H1 for ATB's influence $\left(\beta=0.145, \mathrm{M}=0.060, \mathrm{SD}=0.116, \mathrm{t}=1.202, \mathrm{p}=0.021^{*}\right)$; $\mathrm{H} 2$ for SN's relationship $(\beta=$ $\left.0.083, \mathrm{M}=0.137, \mathrm{SD}=0.094, \mathrm{t}=1.865, \mathrm{p}=0.002^{*} *\right) ; \mathrm{H} 3$ for $\mathrm{PBC}$ 's relationship $(\beta=0.120, \mathrm{M}=0.078, \mathrm{SD}=$ $\left.0.094, \mathrm{t}=2.866, \mathrm{p}=0.001^{* *}\right)$.

Table-3. Significance testing results for the structural model path coefficients.

\begin{tabular}{|c|c|c|c|c|c|c|c|c|}
\hline \multirow[t]{2}{*}{ Hypothesis } & & \multirow[t]{2}{*}{$\mathbf{M}$} & \multirow[t]{2}{*}{ SD } & \multirow[t]{2}{*}{$\mathrm{t}$} & \multirow[t]{2}{*}{$\mathrm{f}^{2}$} & \multicolumn{2}{|c|}{ Effects } & \multirow[t]{2}{*}{ Inference } \\
\hline & & & & & & $\boldsymbol{\beta}$ & p & \\
\hline H1 & ATB $->$ ADIN & 0.060 & 0.116 & $1.202^{*}$ & 0.025 & 0.145 & 0.021 & supported \\
\hline H3 & $\mathrm{PBC} \rightarrow \mathrm{ADIN}$ & 0.078 & 0.094 & $2.866^{* *}$ & 0.016 & 0.120 & 0.001 & upported \\
\hline $\mathrm{H} 4$ & $\mathrm{EE}->\mathrm{ADIN}$ & -0.085 & 0.013 & $1.423^{* *}$ & 0.035 & 0.173 & 0.000 & supported \\
\hline
\end{tabular}

Such predictive significance shows that a government policy of transformation and harmonization in higher education to promote the adoption of M-learning is feasible. High school students in the $21^{\text {st }}$ century are technically inclined to and experienced with digital learning, attaching more importance to their mobile phones than their books. Therefore, a technological innovation policy can positively influence learners to use their mobile phones as study tools, enhancing active learning. Preventing the use of mobile devices in schools for fear of possible misapplication is misplaced in the digital age; it is grounded theory for educational policy, offering the potential to enhance knowledge. Due to the ongoing grievance against the ban on mobile phones in senior high schools (SHS), in some parts of the African continent, including Ghana, the author recommends a policy framework for all education entities across the subregions of the African continent to ensure maximum adoption of M-learning. This will help reduce the doubt and indecision surrounding M-learning, which policymakers have displayed for years when talking to the media, parents, and students.

As detailed earlier, of the two additional constructs of enabling environment (EE) and experience as moderator (E2), the former has weaker significance in adoption intention $\left(\mathrm{CR}=0.685, \mathrm{R}^{2}=-0.189\right)$ than the latter $(\mathrm{CR} 0.778$, $\mathrm{R}^{2}=$ 0.326). Learners' experience with mobile technology thus supports an M-learning policy in schools, in contrast to a lack of educational policy toward creating an enabling environment, as highlighted in Figure 3 (Yen et al., 2017). The TPB analysis is consistent with both the current study and a previous study of behavior in terms of young residents' intention to use urban green spaces in Phnom Penh, because the attitude, subjective norms, and perceived behavioral control all satisfy the construct. In a similar vein to this study, Baek et al. (2017) examined the attitudes of teachers in Korea and found that of three dimensions, attitudes were highest for the Forms of Mobile Learning Application and Tools' Sufficient Adequacy of Communication (FMA\&TSAC). By implication, more teachers and professionals accept M-learning for teacher-learner exchanges. Another study Rahimi and Miri (2014) revealed the advantage of a mobile dictionary for high school students to easily and conveniently learn new words within the school environment, resulting in a positive learning performance. To conclude, Figure 3 shows that the loadings for both observed and unobserved variables exceed the threshold of 0.7 (Claes and David, 2012) 
confirming the theory that M-learning is a vital factor in transforming school education and enhancing learners' experience.

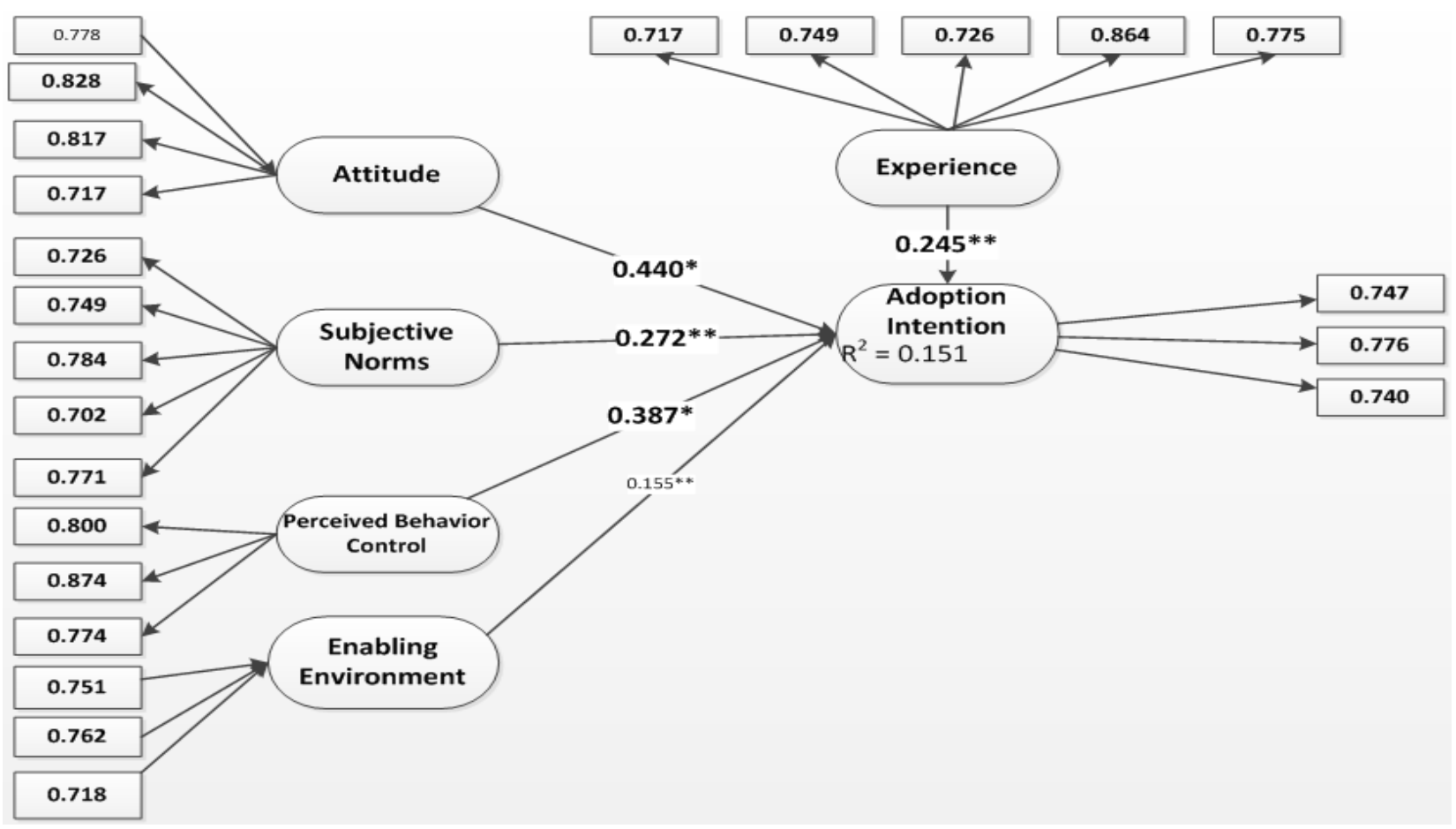

Figure-3. Conceptual Model Indicator Loadings.

\section{DISCUSSION}

In this study, the psychological impact of TPB in encouraging adoption intention for an M-learning policy in higher education is revealed because all the measured constructs significantly support the hypotheses. These results indicate the accepting attitudes and subjective norms exhibited by the school learners in their use of M-learning. Moreover, the study revealed that effective investigations would enhance the integration of government policies on M-learning in developing countries. The TPB core constructs provide predictive significance to the research, along with the additional variables of learners' experience with mobile devices in an enabling environment-in this case, the school.

In effect, the adoption of M-learning depends on students' attitudes, subjective norms in teachers' experiences, and expertise in the technology. Studies on M-learning have found that any new technology must be compatible with users' prior experience and habits if it is to be accepted; this fact, in conjunction with trends in modern learning concepts, will exert a strong influence on adoption intention (Marquez et al., 2015). The author discovered that learners surreptitiously use mobile phones in school, through online chat with their peers and downloading learning materials for their personal study. Thus, both the constructs of enabling environment and experience satisfactorily supported the hypotheses of this study. However, all current M-learning activities in schools lack a policy framework, which the emails received from teachers and professionals with ICT expertise advocated. A government policy would not only enable the smooth implementation of M-learning but also facilitate progress across the subregions on the African continent in the future, which is threatened by learners' clandestine use of mobile devices (Asare and Nti, 2014).

A survey by Africa Tracking Internet Progress found that attitudes toward M-learning in developing countries is encouraging: about 1.5 million high school students own mobile phones, illustrating that $72 \%$ are downloading learning materials, while $46 \%$ had no internet access but wished to use it; the research therefore suggested that a government policy on M-learning was essential before young people developed bad habits with the technology 
(GSS \& GDHS, 2008); (Al-Emran et al., 2016). The study has been corroborated by a professional educationalist from a pilot program incorporating mobile devices into e-learning, reducing the pressure of demand for PCs and laptops, and demonstrating how M-learning offers a cheaper alternative. Therefore, this study proposes regulatory legislation to use an M-learning policy as a complement to e-learning and ICT in developing African countries.

\section{CONCLUSION}

By using the TPB theory, this study has discovered behaviors underpinning an intention to adopt an Mlearning policy in higher education, professionals' perspectives in developing countries, and that experience and an enabling environment are statistically significant to adoption intention. While these results constitute a comprehensive assessment of learners' intentions, the lack of a government policy is a hindrance to the development, application, and exploration of M-learning. However, targeting high school students in developing countries only might not be fully representative, especially due to the exclusion of elites and parents. Thus, further research could investigate the perspectives of policymakers and parents, and others in different subregions of the African continent; this would add more variables on how the adoption of an M-learning policy can be assimilated into higher schools of learning to achieve academic excellence.

Funding: This study received no specific financial support.

Competing Interests: The authors declare that they have no competing interests.

Contributors/Acknowledgement: All authors contributed equally to the conception and design of the study.

\section{REFERENCES}

Abu-Al-Aish, A., 2014. Toward mobile learning deployment in higher education. Doctoral Dissertation, Brunel University, School of Information Systems, Computing and Mathematics.

Aimran, A.N., S. Ahmad, A. Afthanorhan and Z. Awang, 2017. The assessment of the performance of covariance-based structural equation modeling and partial least square path modeling. AIP Conference Proceedings, 1842.Available at: https://doi.org/10.1063/1.4982839.

Ajzen, I., 1991. The theory of planned behavior. Organizational Behavior and Human Decision Processes, 50(2): 179-21 1.

Al-alak, B.A. and I.A. Alnawas, 2011. Measuring the acceptance and adoption of e-learning by academic staff. Knowledge Management \& E-Learning: An International Journal, 3(2): 201-221.

Al-Emran, M., H.M. Elsherif and K. Shaalan, 2016. Investigating attitudes towards the use of mobile learning in higher education. Computers in Human Behavior, 56: 93-102.Available at: https://doi.org/10.1016/j.chb.2015.11.033

Asare, K.B. and S.K. Nti, 2014. Teacher education in Ghana: A contemporary synopsis and matters arising. SAGE Open, 4(2): 2158244014529781. Available at: https://doi.org/10.1177/2158244014529781.

Baek, Y., H. Zhang and S. Yun, 2017. Teachers' attitudes toward mobile learning in Korea. Turkish Online Journal of Educational Technology, 16(1): 154-163.

Beglar, D. and T. Nemoto, 2014. Developing Likert-scale questionnaires. In JALT2013 Conference Proceedings. pp: 1-8.

Beutner, M. and F.A. Rüscher, 2017. Acceptance of mobile learning at SMEs of the service sector. International Association for Development of the Information Society. pp: 63-70.

Bird, P. and M. Stubbs, 2015. It's not just the pedagogy: Challenges in scaling mobile learning applications into institution-wide learning technologies. International Association for Development of the Information Society.

Bodoff, D. and S.Y. Ho, 2016. Partial least squares structural equation modeling approach for analyzing a model with a binary indicator as an endogenous variable. Communications of the Association for Information Systems, 38(1): 400419.Available at: https://doi.org/10.17705/1CAIS.03823.

Bonett, D.G. and T.A. Wright, 2015. Cronbach's alpha reliability: Interval estimation, hypothesis testing, and sample size planning. Journal of Organizational Behavior, 36(1): 3-15.Available at: https://doi.org/10.1002/job.1960. 
Borrás, S. and C. Edquist, 2013. The choice of innovation policy instruments. Technological Forecasting and Social Change, 80(8): 1513-1522.Available at: https://doi.org/10.1016/j.techfore.2013.03.002.

Brahimi, T. and A. Sarirete, 2015. Learning outside the classroom through MOOCs. Computers in Human Behavior, 51: 604609.Available at: https://doi.org/10.1016/j.chb.2015.03.013.

Burden, K.J. and M. Kearney, 2017. Investigating and critiquing teacher educators' mobile learning practices. Interactive Technology and Smart Education, 14(2): 110-125.Available at: https://doi.org/10.1108/ITSE-05-2017-0027.

Castillo, S.L. and G. Ayala, 2012. Mobile learning. Encyclopedia of Sciences of Learning: 2293-2295.Available at: https://doi.org/10.1017/CBO9781139519526.030.

Claes, F. and F.L. David, 2012. Evaluating structural equation models with unobservable variables and measurement error. Journal of American Marketing Association, 18(1): 39-50.

Crogman, H. and M. Trebeau Crogman, 2018. Modified generated question learning, and its classroom implementation and assessment. Cogent Education, 5(1): 1459340.Available at: https://doi.org/10.1080/2331 186X.2018.1459340.

Crompton, H., 2013. A historical overview of m learning: Toward learner-centred education. Handbook of mobile learning. 1st Edn., New York: Routledge. pp: 680. Available from: https://doi.org/10.4324/9780203118764.

Dedrick, J., K.L. Kraemer and E. Shih, 2013. Information technology and productivity in developed and developing countries. Journal of Management Information Systems, 30(1): 97-122.Available at: https://doi.org/10.2753/mis07421222300103.

Drigas, A. and M. Pappas, 2015. A review of mobile learning applications for mathematics. International Journal of Interactive Mobile Technologies, 9(3): 18-23.Available at: https://doi.org/10.3991/ijim.v9i3.4420.

Fishbein, M. and J.N. Cappella, 2006. The role of theory in developing effective health communications. Journal of Communication, 56(suppl_1): S1-S17.Available at: https://doi.org/10.1111/j.1460-2466.2006.00280.x.

Fornell, C. and D.F. Larcker, 2016. Evaluating structural equation models with unobservable variables and measurement error. Journal of Marketing Research, 18(1): 39-50.

Gates, B., 2009. 2009 annual letter. United States, Medina, Washington. Available from papers3://publication/uuid/1612D6Fo4D76-4FoC-A7E9-E4D933479E59.

Ghana Statistical Service \& Ghana Demographic Health Survey, 2008. Ghana demographic and health survey 2008: Ghana statistical service, Ghana health service, Ghana AIDS commission. Ghana Statistical Service (GSS) Ghana Demographic and Health Survey. Available from https://doi.org/10.15171/ijhpm.2016.42.

Hair, J.F., C.M. Ringle and M. Sarstedt, 2013. Partial least squares structural equation modeling: Rigorous applications, better results and higher acceptance. Long Range Planning, 46(1-2): 1-12.Available at: https://doi.org/10.1016/j.lrp.2013.01.001.

Hair, J.F., M. Sarstedt, T.M. Pieper and C.M. Ringle, 2012a. The use of partial least squares structural equation modeling in strategic management research: A review of past practices and recommendations for future applications. Long Range Planning, 45(5-6): 320-340.Available at: https://doi.org/10.1016/j.lrp.2012.09.008.

Henseler, J., C.M. Ringle and M. Sarstedt, 2015. A new criterion for assessing discriminant validity in variance-based structural equation modeling. Journal of the Academy of Marketing Science, 43(1): 115-135.Available at: https://doi.org/10.1007/s11747-014-0403-8.

IBM, 2015. SPSS software. Predictive analytics software and solutions, 1. Available from http://www01.ibm.com/software/analytics/spss/.

Ireri, B.N. and E.I. Omwenga, 2016. Mobile learning: A bridging technology of learner entry behavior in a flipped classroom model. In Handbook of Research on Active Learning and the Flipped Classroom Model in the Digital Age. pp: 106121. Available from https://doi.org/10.4018/9781-4666-9680-8.

Kabanda, S. and I. Brown, 2017. A structuration analysis of small and medium enterprise (SME) adoption of E-Commerce: The case of Tanzania. Telematics and Informatics, 34(4): 118-132.Available at: https://doi.org/10.1016/j.tele.2017.01.002. 
Kangas, M., P. Siklander, J. Randolph and H. Ruokamo, 2017. Teachers' engagement and students' satisfaction with a playful learning environment. Teaching and Teacher Education, 63: 274-284.Available at: https://doi.org/10.1016/j.tate.2016.12.018.

Karimi, S., 2016. Do learners' characteristics matter? An exploration of mobile-learning adoption in self-directed learning. Computers in Human Behavior, 63: 769-776.Available at: https://doi.org/10.1016/j.chb.2016.06.014.

Khan, I.U., Z. Hameed, Y. Yu, T. Islam, Z. Sheikh and S.U. Khan, 2018. Predicting the acceptance of MOOCs in a developing country: Application of task-technology fit model, social motivation, and self-determination theory. Telematics and Informatics, 35(4): 964-978.Available at: https://doi.org/10.1016/j.tele.2017.09.009.

Kimiloglu, H., M. Ozturan and B. Kutlu, 2017. Perceptions about and attitude toward the usage of e-learning in corporate training. Computers in Human Behavior, 72: 339-349.Available at: https://doi.org/10.1016/j.chb.2017.02.062.

Levy, S., 2015. How google is taking search outside the box. Available from https://medium.com/backchannel/how-google-istaking-search-outside-the-box-678e794e07bf.

Li, Y.W., 2016. Transforming conventional teaching classroom to learner-centred teaching classroom using multimediamediated learning module. International Journal of Information and Education Technology, 6(2): 105-1 12.Available at: https://doi.org/10.7763/ijiet.2016.v6.667.

Likert, R., 1932. A technique for the measurement of attitudes. Archives of Psychology.

Looi, C.-K., D. Sun, L. Wu, P. Seow, G. Chia, L.-H. Wong, E. Soloway and C. Norris, 2014. Implementing mobile learning curricula in a grade level: Empirical study of learning effectiveness at scale. Computers \& Education, 77: 101115.Available at: https://doi.org/10.1016/j.compedu.2014.04.011.

Marquez, J.J., A. Downey and R. Clement, 2015. Walking a mile in the user's shoes: Customer journey mapping as a method to understanding the user experience. Internet Reference Services Quarterly, 20(3-4): 135-150.Available at: https://doi.org/10.1080/10875301.2015.1107000.

Mcneish, D., 2017. Psychological methods thanks coefficient alpha, we will take it from here.

Mehdipour, Y. and H. Zerehkafi, 2013. Mobile learning for education: Benefits and challenges. International Journal of Computational Engineering Research, 3(6): 93-101.

Noar, S.M. and R.S. Zimmerman, 2005. Health behavior theory and cumulative knowledge regarding health behaviors: Are we moving in the right direction? Health Education Research, 20(3): 275-290.Available at: ttps://doi.org/10.1093/her/cyg113.

Osakwe, J., N. Dlodlo and N. Jere, 2017. Where learners' and teachers' perceptions on mobile learning meet: A case of Namibian secondary schools in the Khomas region. Technology in Society, 49: 16-30.Available at: https://doi.org/10.1016/j.techsoc.2016.12.004.

Park, Y., 2011. A pedagogical framework for mobile learning: Categorizing educational applications of mobile technologies into four types. The International Review of Research in Open and Distributed Learning, 12(2): 78-102.Available at: https://doi.org/10.19173/irrodl.v12i2.791.

Peeters, J., F. De Backer, T. Buffel, A. Kindekens, K. Struyven, C. Zhu and K. Lombaerts, 2014. Adult learners' informal learning experiences in formal education setting. Journal of Adult Development, 21(3): 181-192.Available at: https://doi.org/10.1007/s10804-014-9190-1.

Pegrum, M., G. Oakley and R. Faulkner, 2013. Schools going mobile: A study of the adoption of mobile handheld technologies in Western Australian independent schools. Australasian Journal of Educational Technology, 29(1): 66-81.Available at: https://doi.org/10.14742/ajet.64.

Quaye, F., 2015. The impact of ICT on teaching and learning in tertiary institutions : A case study of Wisconsin International University, 5(5): 8-15.

Rahimi, M. and S.S. Miri, 2014. The impact of mobile dictionary use on language learning. Procedia-Social and Behavioral Sciences, 98: 1469-1474.Available at: https://doi.org/10.1016/j.sbspro.2014.03.567. 
Rönkkö, M. and J. Ylitalo, 2011. PLS marker variable approach to diagnosing and controlling for method variance. In Thirty Second International Conference on Information Systems, Shanghai 2011. pp: 222-223. Available from: https://doi.org/10.1007/978-1-4614-8283-3.

Sayibu, M., Z. Suiling, S.A. Alammash and A.A. Ahmed, 2018. Technology innovation of M learning as an administrative largesse : The moderating role of experience, 7(11): 231-248.

Serrano-Laguna, Á., J. Torrente, P. Moreno-Ger and B. Fernández-Manjón, 2014. Application of learning analytics in educational videogames. Entertainment Computing, $5(4)$ : 313-322.Available at: https://doi.org/10.1016/j.entcom.2014.02.003.

Skinner, B.F., 1971. Beyond freedom and human dignity. Hamilton College, Harvard University, Susquehanna, Pennsylvania.

Sobaih, A.E.E., M.A. Moustafa, P. Ghandforoush and M. Khan, 2016. To use or not to use? Social media in higher education in developing countries. Computers in Human Behavior, 58: 296-305.Available at: https://doi.org/10.1016/j.chb.2016.01.002.

Songer-Nocks, E., 1976. Reply to fishbein and ajzen. Journal of Experimental Social Psychology, 12(6): 585-590.Available at: https://doi.org/10.1016/0022-1031(76)90037-8.

Sung, Y.T., K.E. Chang and T.C. Liu, 2016. The effects of integrating mobile devices with teaching and learning on students' learning performance: A meta-analysis and research synthesis. Computers \& Education, 94: 252-275.Available at: https://doi.org/10.1016/j.compedu.2015.11.008.

Venkatesh, V., M.G. Morris, G.B. Davis and F.D. Davis, 2003. User acceptance of information technology: Toward a unified view. MIS Quarterly, 27(3): 425-478.Available at: https://doi.org/10.2307/30036540.

Wada, I., 2018. Cloud computing implementation in libraries: A synergy for library services optimization. International Journal of Library and Information Science, 10(2): 17-27.Available at: https://doi.org/10.5897/IJLIS20 16.0748.

West, M. and S. Vosloo, 2013. UNESCO Policy guidelines for mobile learning. UNESCO Working Paper Series on Mobile Learning. Available from http://unesdoc.unesco.org/images/002 1/002196/219641e.pdf.

Wongwatkit, C., P. Panjaburee and N. Srisawasdi, 2017. A proposal to develop a guided-inquiry mobile learning with a mastery learning mechanism for improving students' learning performance and attitudes in physics. International Journal of Mobile Learning and Organisation, 11(1): 63-86.Available at: https://doi.org/10.1504/ijmlo.2017.080898.

Xie, Q., W. Song, X. Peng and M. Shabbir, 2017. Predictors for e-government adoption: Integrating TAM, TPB, trust and perceived risk. The Electronic Library, 35(1): 2-20.Available at: https://doi.org/10.1 108/el-08-2015-0141.

Yagci, T., 2015. Blended learning via mobile social media \& implementation of" EDMODO" in reading classes. Advances in Language and Literary Studies, 6(4): 41-47.Available at: https://doi.org/10.7575/aiac.alls.v.6n.4p.41.

Yen, Y., Z. Wang, Y. Shi, F. Xu, B. Soeung, M.T. Sohail, G. Rubakula and S.A. Juma, 2017. The predictors of the behavioral intention to the use of urban green spaces: The perspectives of young residents in Phnom Penh, Cambodia. Habitat International, 64: 98-108.Available at: https://doi.org/10.1016/j.habitatint.2017.04.009.

\section{APPENDIX}

The Adoption of an M-Learning Policy in Higher Education: The Professionals' Perspective in Developing Countries

A standardized attitudinal scale survey instrument adapted for participants to respond using a 5-point Likert scale: from (1) STRONGLY DISAGREED (SD), (2) DISAGREED (D), (3) UNDECIDED (UN), (4) AGREED (A), to (5) STRONGLY AGREED (SA).

Dear Respondent,

This study intends to investigate the adoption of a mobile learning (M-learning) policy in higher education, to encourage learner's efficient and effective use of technology for better learning outcomes. 
This survey also aims to advocate a government policy on mobile technology, which can engage students in "learning by doing" activities and demonstrate that M-learning in schools is not a misplaced priority.

The anonymity and confidentiality of all respondents is guaranteed.

The researcher is a masters' student in the School of Public Affairs at the University of Science and Technology of China (USTC). Please answer all the questions honestly according to your actual observations and attitudes. All the information will be used for purely academic, and not for any commercial, purpose. Thank you for taking the time to complete this questionnaire, and please accept my heartfelt appreciation!

\section{Demographic Profile}

1. Gender

2. Age range

3. Level of education

\begin{tabular}{l|l}
\hline Female & \\
\hline Male & \\
\hline
\end{tabular}

\begin{tabular}{l|l}
\hline$<15$ Yrs & \\
\hline $16-18$ Yrs & \\
\hline $19-22$ Yrs & \\
\hline $23-25$ Yrs & \\
\hline $26-30$ Yrs & \\
\hline
\end{tabular}

\begin{tabular}{l|l}
\hline JHS & \\
\hline SHS/Middle & \\
\hline Bachelors & \\
\hline
\end{tabular}

4. Are you a mobile phone user?

5. Country or region:

\begin{tabular}{l|l}
\hline Yes & \\
\hline No & \\
\hline
\end{tabular}

Descriptions of the Main Variables in this Research Study

Behavior Intention (BI): Learners' instinctive motivation to consciously plan or decide to use mobile learning (Mlearning) inside or outside school, or for a specific learning outcome.

6. Mobile learning is a good initiative for future regulations in education.

7. I intend to use mobile learning in the dormitory.

8. I prefer to use mobile learning than the computer.

9. I sometimes use mobile learning for reading.

10. I want to use mobile learning for further research.

Adoption Intention (ADIN): Learners' strong inclination toward or interest in accepting mobile learning technology in education.

\begin{tabular}{l|l}
\hline ADIN & $\begin{array}{l}\text { 11. I intend to use mobile learning in school in my search for } \\
\text { knowledge. }\end{array}$ \\
\cline { 2 - 3 } $\begin{array}{l}\text { 12. I will continue to use mobile learning in the school, NOT the } \\
\text { classroom. }\end{array}$ \\
\cline { 2 - 2 } $\begin{array}{l}\text { 13. The use of mobile learning is now a portable and useful tool in } \\
\text { education. }\end{array}$ \\
\cline { 2 - 2 } & $\mathbf{1 4 .}$ I will recommend mobile learning to others in high schools. \\
\hline
\end{tabular}


Perceived Self-Learning Usefulness (PSLU): Learners believe that using mobile learning (M-learning) will personally enhance their academic performance without an instructor (tutor): "learning by doing."

\begin{tabular}{|c|c|}
\hline \multirow[t]{5}{*}{ PSLU } & $\begin{array}{l}\text { 15. I think using mobile learning would make it easier for me to search } \\
\text { for learning materials. }\end{array}$ \\
\hline & $\begin{array}{l}\text { 16. Using mobile learning would make it easier for me to discuss } \\
\text { topics with teachers online. }\end{array}$ \\
\hline & $\begin{array}{l}\text { 17. Using mobile learning enables me to quickly take notes via social } \\
\text { media (WeChat, WhatsApp). }\end{array}$ \\
\hline & $\begin{array}{l}\text { 18. Using mobile learning will enable me to read anywhere I am more } \\
\text { effectively. }\end{array}$ \\
\hline & 19. I find mobile learning very useful in the digital age. \\
\hline
\end{tabular}

Perceived Ease of Use (PEOU): Learners believe using mobile learning (M-learning) technology is easy, effortless, or accessible.

\begin{tabular}{c|c}
\hline PEOU & $\begin{array}{l}\text { 20. I think learning to use mobile learning is easy for high school } \\
\text { students. }\end{array}$ \\
\cline { 2 - 3 } & $\begin{array}{l}\mathbf{2 1 .} \text { I think finding what I want via mobile learning is practical and } \\
\text { undemanding. }\end{array}$ \\
\cline { 2 - 3 } & $\begin{array}{l}\mathbf{2 2} \text { I think the skill in mobile learning is having quick access to a } \\
\text { phone. }\end{array}$ \\
\cline { 2 - 3 } & $\mathbf{2 3 .}$ I think using mobile learning motivates students. \\
\hline
\end{tabular}

Attitude toward Behavior (ATB): An individual's evaluative feelings about and interest in an action, as well as the outcome from performing the action. Innovation is the outcome of habit linked with interest in the work.

\begin{tabular}{|c|c|}
\hline \multirow[t]{5}{*}{ ATT } & $\begin{array}{l}\text { 24. I think students' addiction to phones facilitates mobile learning as } \\
\text { a useful tool for academics in schools. }\end{array}$ \\
\hline & 25. Students' access to mobile phones facilitates M-learning. \\
\hline & $\begin{array}{l}\text { 26. Students' typical usage of phones means mobile learning is more of } \\
\text { a hobby. }\end{array}$ \\
\hline & 27. Mobile learning makes reading enjoyable and exciting. \\
\hline & 28. I think the use of mobile learning has become a habit. \\
\hline
\end{tabular}

Subjective Norms (SN): Learners' perception of social norms or pressure from teachers and authorities to undertake mobile learning (M-learning), and of regulations for the use of technology in schools.

\begin{tabular}{|c|c|}
\hline \multirow[t]{5}{*}{$\mathbf{S N}$} & 29. Most teachers/learners' now approve of mobile learning in schools. \\
\hline & 30. School friends think mobile learning is a good idea for online chat. \\
\hline & 31. I think regulations will help implementation. \\
\hline & 32. Using mobile learning alongside formal education is fun. \\
\hline & $\begin{array}{l}\text { 33. Society thinks mobile learning should be avoided to deter students' } \\
\text { misuse of phones. }\end{array}$ \\
\hline
\end{tabular}

Perceived Behavioral Control (PBC): Whether experts perceive performing an action (the means) will be easy or difficult to implement with a mobile learning (M-learning) policy.

\begin{tabular}{|c|c|}
\hline \multirow[t]{4}{*}{ PBC } & 34. Using mobile learning is a matter of choice and interest. \\
\hline & 35. Mobile learning is a good idea in schools. \\
\hline & 36. I prefer using mobile to computer-based learning in schools. \\
\hline & $\begin{array}{l}\text { 37. Every student now owns a mobile phone for mobile learning in } \\
\text { schools. }\end{array}$ \\
\hline
\end{tabular}


Enabling Environment (EE): The physical or social setting (the environment) that facilitates learners' use of mobile learning to easily and calmly acquire knowledge.

\begin{tabular}{|c|c|}
\hline \multirow{4}{*}{$\mathbf{E E}$} & 38. I use mobile learning in parts of the school. \\
\hline & 39. I plan to use mobile learning in the school dormitories. \\
\hline & 40. I will use mobile learning everywhere or somewhere in the school. \\
\hline & $\begin{array}{l}\text { 41. I will use mobile learning for group discussion on social media } \\
\text { anywhere in the school. }\end{array}$ \\
\hline
\end{tabular}

Views and opinions expressed in this article are the views and opinions of the author(s), Humanities and Social Sciences Letters shall not be responsible or answerable for any loss, damage or liability etc. caused in relation to/arising out of the use of the content. 